\title{
Challenge for the Design and Construction of Jakarta MRT from Geotechnical and Traffic Engineering Perspectives
}

\author{
Paulus P, Rahardjo ${ }^{\mathrm{a}}$, Anastasia Caroline Sutandi ${ }^{\mathrm{a}^{*}}$ \\ ${ }^{a}$ Civil Engineering Department, Faculty of Engineering, Parahyangan Catholic University, Ciumbuleuit 94, Bandung, Indonesia \\ E-mail: "caroline@unpar.ac.id
}

\begin{abstract}
Traffic condition in Jakarta has reached critical level without the support of adequate public transportation. Jakarta MRT is another transportation mode proposed for the solution. However, this system will not respond to the issue without integration with existing transportation modes i.e., Bus-Trans-Jakarta and LRT. This paper discusses the geotechnical and traffic engineering aspects of the design and construction of Jakarta MRT. In geotechnical perspectives, the fact that soil conditions in Jakarta are soft, so construction requires careful design and method to reduce disturbance to existing traffic conditions. Diaphragm wall used with topdown construction has been proved as the best solution and the use of TBM is required. In traffic engineering perspectives, all existing transportation modes are considered in the determination of MRT station locations as well as the challenge of substructures construction in the soft soil area. Considering public safety during construction, it has been designed with combined elevated railways at the south corridor and subway in the northern corridor. This study concluded that the selection of the station locations considering integrated all public transportation modes is a must and the construction method for subsurface structures should be selected carefully to reduce traffic disturbance in Jakarta and to keep public safety.
\end{abstract}

Keywords - Mass Rapid Transit (MRT); integrated transportation system; diaphragm wall; top-down construction.

\section{INTRODUCTION}

The fast increase in the population and vehicle growth and also economic development in large cities in a developing country like Indonesia is unprecedented. Jakarta as the capital city of Indonesia, experiences 0.9 percent population growth and 12 percent vehicle growth per year that is very high values. Nowadays, there are around 10.1 million population and 17.4 million vehicles [1], [2]. These factors result in traffic problems in the city and have been very critical. Such developments require a more integrated public transportation system [3]-[9].

Civil Engineering is "promoting the use of geotechnical information in the methods of construction of subsurface ground facilities of Jakarta MRT for public safety and traffic engineering offer the solution on the change of the existing and future transportation modes as well as the traffic management to reduce problems during the construction period which may take a few years. Besides the involvement of scientists, professionals (planners, geologists, engineers) and decision-makers, it is essential that they understand each other well, both in cases of communication and in cases of using the knowledge and analysis of each other [10].

The difficulties of the geotechnical engineering process for the construction of urban infrastructures seem to be limited interests of urban planners and decision-makers related to geotechnical constraints. The Asian Technical Committee (ATC) of Geo-Urban Engineering and the Technical Committee on Geotechnical for Mega Infrastructures have been created by the International Society of Soil Mechanics and Geotechnical Engineering to bridge these issues.

The difficulties of traffic engineering process for infrastructures in the urban area is time and construction method during construction to less disturbing to existing traffic and still a concern to road safety first. Furthermore, the location of MRT stations has to be located in a densely populated area and have to be integrated with all existing transportation modes i.e. bus-Trans-Jakarta and LRT [11], [12].

In most cases, knowledge and information concerning developmental conditions are postponed until the moment of realization and construction efforts, in this stage, these conditions create sophisticated preparation of urban traffic as well as geotechnical solutions. At present, the Jakarta Public Works authority explicitly requires a geotechnical and structural design to be approved and recommended by the expert team called TABG (Team Ahli Bangunan Gedung) before construction can be started. The plan for Jakarta MRT and the present status of its construction has been part of the discussion at the TABG office for technical assessment; 
however, the other mode of transportation might be regulated under the other ministry (transportation) hence there may be problems during their implementation.

\section{A. Plan for Integrated Transportation Mode for Jakarta}

The face of the Jakarta transportation system will change for the Asian Games 2018. The Jakarta Mass Rapid Transit (MRT) from Lebak Bulus to Bundaran HI and the Light Rail Transit (LRT) from Cibubur-Cawang-Grogol will be expected to open by 2018. Out of 7 routes of LRT, two routes are planned to be completed before the 2018 Asian Games in Indonesia. The two LRT routes include Kebayoran Lama-Kelapa Gading and Kelapa Gading-KemayoranPesing-Soekarno Hatta Airport.

Both MRT and LRT are a necessity for Jakarta if she wants to survive from her daily traffic jams. In 2010, the number of cars produced was 702.508 units, while in 2013 , it has increased by 1.208.211 units yearly. The Association of Motor Vehiclesmentioned that the number of cars motorcycles in Jakarta has reached 8 million units. Data from Kepolisian Daerah Metro Jaya (Jakarta Traffic Police Headquarter) that the number of cars and motorcycles in the area of Jakarta, Tangerang, Bekasi, and Depok in 2013 has been 16.1 million units, of which 12 million were motorcycles and 4.1 million cars. Those from outside Jakarta are commuters. It is reasonable why traffic jams are seen daily in Jakarta almost everywhere. The increase in the number of cars and motorcycles is $11.2 \%$ on average and the development of roads in Jakarta is only $0.01 \%$ every year. For 12 million of the population, Jakarta should have 12,000 $\mathrm{km}$ of roads while the length of available roads is only $60 \%$ or $7.208 \mathrm{~km} \mathrm{[13].}$

Jakarta MRT has been designed as one of the integrated transportation modes to solve the problems of traffic jams in Jakarta City. The mission is to provide transportation for the public to develop economic growth through the increase in mobility, reduction in travel time, and development of the Jakarta Traffic System. The most important factor for transportation instrument is "community will to change". if Jakarta MRT can be developed as comfortable and safe transportation means, it can be "magnet" for the people who are still depending on the private vehicles, especially if MRT is connected well with other transportation modes such as KRL, Trans-Jakarta, LRT and future development of airport trains.

It is expected that the existence of Jakarta MRT will be able to make changes in the community culture and mobility. They could even increase the quality of life and lifestyle. Jakarta people and the commuters will erase traffic problems by making advantages of public transportation like one in Singapore and maybe in other developed countries.

\section{B. Integration of Jakarta MRT with Other Public Transportation}

Jakarta MRT will be operated based on international standards, meaning that the users will have reliable safety and comforts. It should not cause any traffic congestions and also will automatically create feeders by integration with another public transport system. The capacity of one lift could be a maximum of 1,200 people.

At least one station (Dukuh Atas) will be integrated with four other public transportation (i.e., Commuter Line), LRT, Airport Trains, and Trans-Jakarta. However, at every elevated station as well as the underground station, they are easily reached by a safe pedestrian corridor to enable the safety of the users to continue their transportation from one mode to another.

The first phase of Jakarta MRT consisting of the elevated structure at about $10 \mathrm{~km}$ from Lebak Bulus to Sisingamangaraja (with seven stations: Lebak Bulus, Fatmawati, Cipete Raya, Haji Nawi, Blok A, Blok M and Sisingamangaraja) with the transition to the underground structure. The depo will be located at Lebakbulus. The underground part consists of 6 stations (Senayan, Istora, Bendungan Hilir, Setiabudi, Dukuh Atas and Bunderan Hotel Indonesia. Figure 1 shows the position of the MRT stations and Figure 2 shows the example of the integrated future station in Jakarta. Figure 3 describes the expected situation when Jakarta MRT has been completed. The use of underground space and upper ground space is to limit the disturbance of the existing traffic condition.

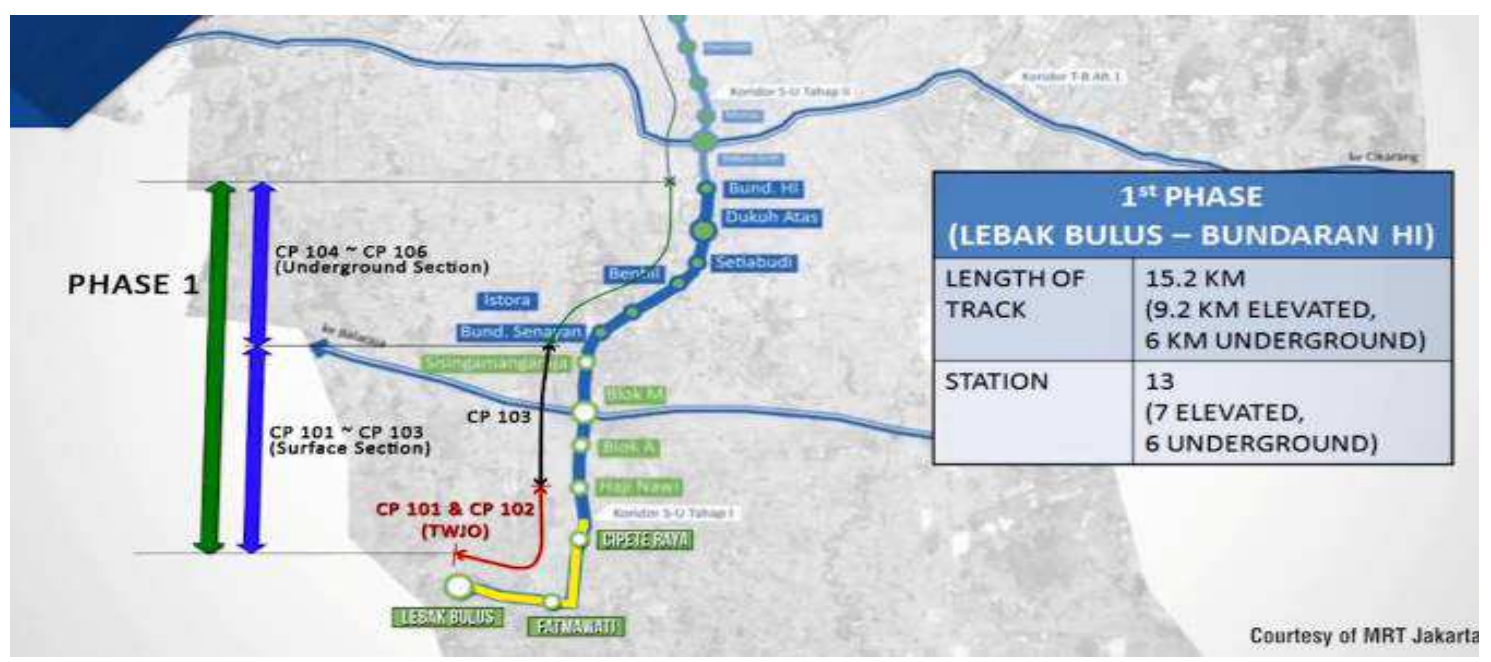

Fig. 1 Jakarta MRT - phase 1 (courtesy of Jakarta MRT) 


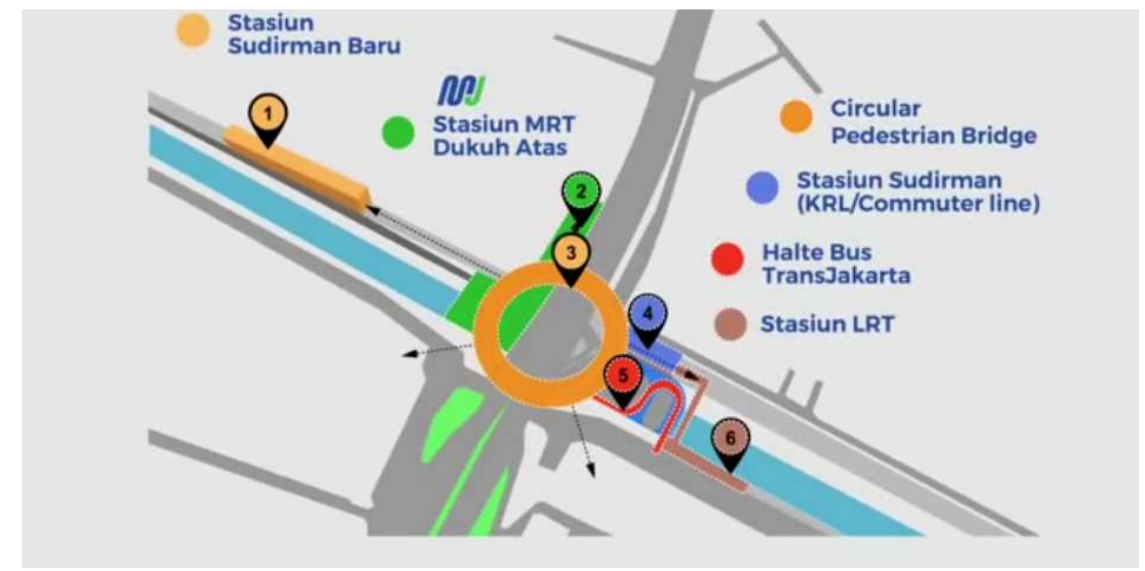

Fig. 2 Example of Future Integrated Transportation System (courtesy of Jakarta MRT)

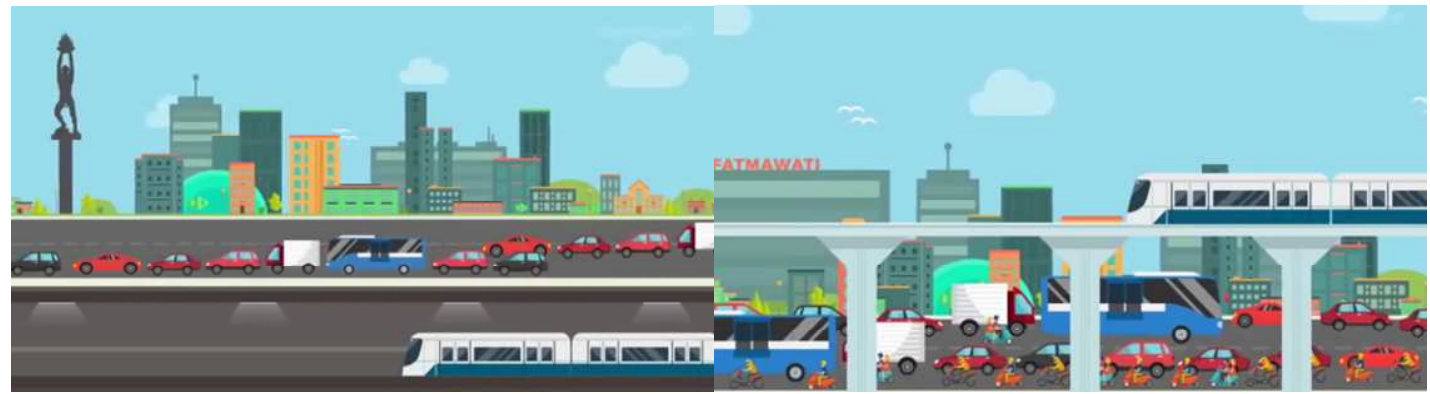

Fig. 3 Expected Traffic Situation during operation of Jakarta - MRT (courtesy of J-MRT)

The challenge in design and construction are quite demanding. Jakarta, with dense traffic every day is not an easy job. The best solution to solve this problem is by use of substructure of tunnels; however, the cost will be very high and the risk is also high. Hence the choice of the combined elevated structure at the south side and underground at the north part is considered to be optimal.

The stations of the Jakarta MRT have been planned strategically so that people will have access to the final destination within walking distance (meaning that the distance between stations will be about 700-1200 $\mathrm{m}$ or the intermediate destinations are connected to the other public transportation system. This paper does not discuss in detail how the transportation modes are to be integrated, instead of that it is mentioned the importance of the integration such as using one means for transportation like the same traveling card like flash-cards.

Figure 4 and Figure 5 are illustrations of the upper ground and underground stations located in the business districts. The design has included the aspect of the Jakarta traffic condition. The upper elevated stations shall take into account the number of people in the rush hour.

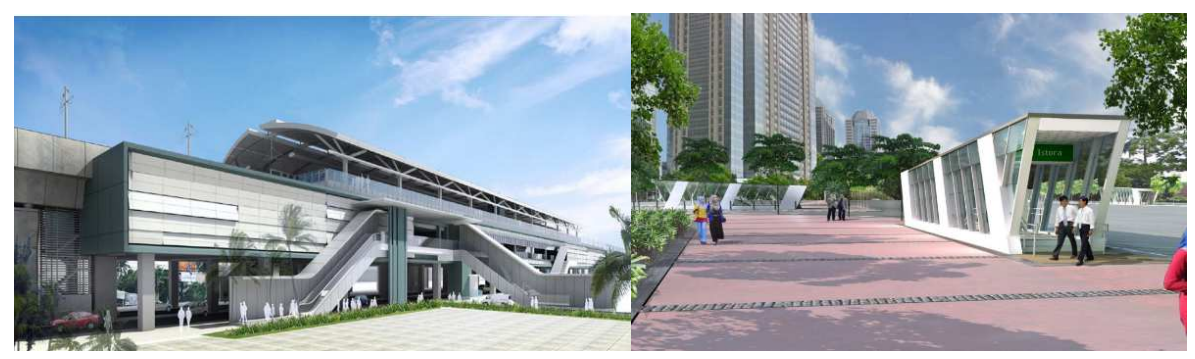

Fig. 4 Lebak Bulus Station and Dukuh Atas Station (courtesy of MRT-J)

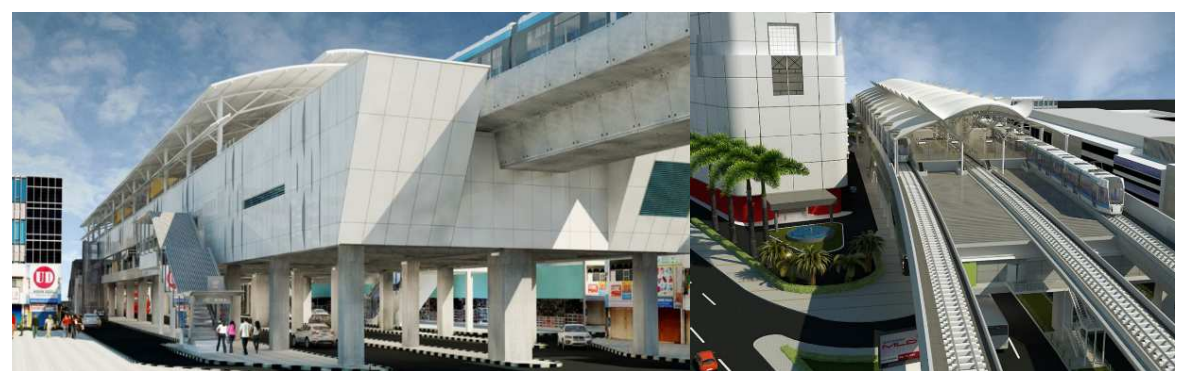

Fig. 5 Blok A Station and Blok M Station (courtesy of MRT-J) 


\section{MATERIAL AND METHODS}

The geological and seismicity challenge of Jakarta city for the construction of MRT-J will be discussed in detail. The physiography of Jakarta City consists of delta plains facing marine sediments, coastal sediments, swamps and alluvium at the north of Jakarta which is geologically deposited in the quaternary period. Many projects in Jakarta show the alluvium consisting of clays and silts and to some extent sands on the surfaces and high-water table [14]. These issues have a significant influence on the safety of underground construction and shall be carefully investigated. The soils at south Jakarta is older with the lower groundwater table, and hence, excavation (for basement or MRT station) generally has less risk.

A study on the Jakarta seismicity also has fundamental aspects of the design of the underground as well as the upper structure. Even though the underground structure is usually safer, however, the damage of substructure during an earthquake may cause fatalities to show, under severe earthquake, the MRT stations and the tunnels in soft soils condition may be distorted as much as $30-50 \mathrm{~cm}$. Another geotechnical aspect that shall be considered is the liquefaction potential of the saturated sand layers due to earthquakes. Phenomena of liquefaction can be in the form of sand blows at several sites, flow liquefaction causing lateral displacement and cyclic mobility. Those three phenomena were causing settlement and loss of shear strength. In the lateral movement, the foundation might have shifted, and land cracks along laterally [14]. The attention shall be focused primarily in the area of the central Jakarta area [8]. Figure 6 shows the seismicity for the Jakarta area from the data provided by USGS (United States Geological Survey) for liquefaction study [15], [16].

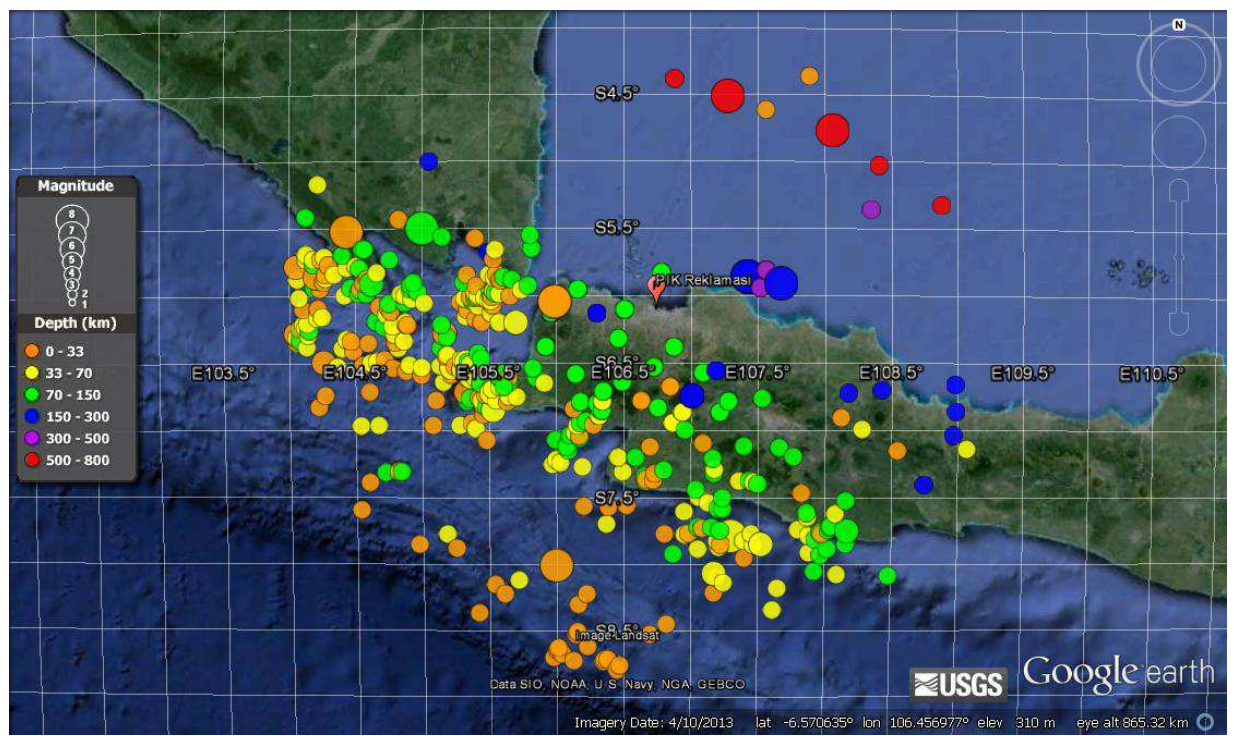

Fig. 6 Seismicity study in the Jakarta Area for Liquefaction Potential Vulnerability [7]

The challenge for design and construction is even more for soft soils in north Jakarta. The North Jakarta soils are deep soft layers. Hence, the excavation may cause movement of the existing foundation. There should be regulation on the design criteria to be developed for this typical soil condition. Limitations on the movement of the foundation shall be rigorous and controlled. 3D finite element analysis may be needed for complicated cases of nearby structures.

\section{RESULTS AND DISCUSSION}

There are several problems to be resolved during the construction of Jakarta MRT from Geotechnical and Traffic problems of the Jakarta MRT construction:

- Managing traffic flow in overall construction: south corridor (elevated) and north corridor (tunnel and open deep excavation for the stations.

- Construction Safety and Maneuver of Heavy Construction.

- Access for vehicles, structural members and concreting in and out of the construction site.
- Management of Groundwater flow and rainwater during construction.

- Effect of tunneling and excavation during the construction of MRT.

\section{A. Managing Traffic Flow during Construction}

Traffic jams have been everyday life for Jakarta. Hence the construction of MRT causes more complexity. Traffic management is a critical aspect; it is not only a matter of directing the traffic surrounding the construction and putting clear signs. Difficulties include socialization to the Jakarta communities that took a long time before people and road users realize that there will be traffic diversions. Long before the beginning of construction, traffic signs and information on the upcoming project has been announced.

In the south corridor, the difficulties are more pronounced due to the exposure of all structures. Especially at the crossing and junction, the traffic signs and information must be distinct and traffic flows shall be properly directed to avoid the worse condition of traffic jams (Figure 7). 


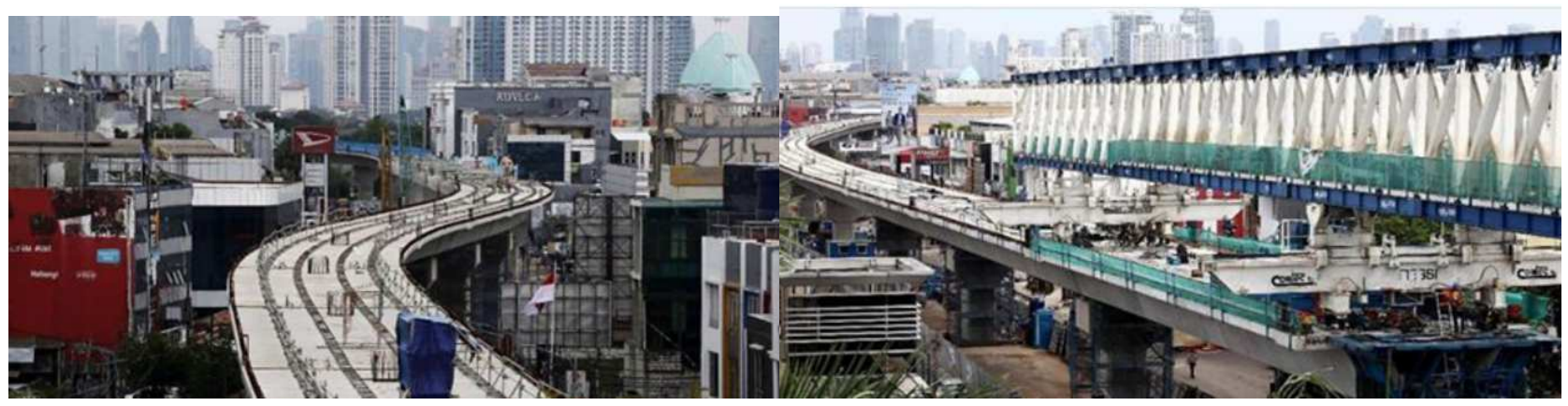

Fig. 7 The challenge of Traffic Diversion for Construction in the South Corridor

In the north corridor, the problems are easier to handle because there are underground tunnel parts and stations. The tunnel part practically does not need space; however, at the locations of the stations, full space is needed to open excavation. Figure 8 shows how traffic is squeezed into fewer traffic lanes while the busway lanes are still provided. Figure 9 is the bird eye view of the traffic situation in the north corridor.

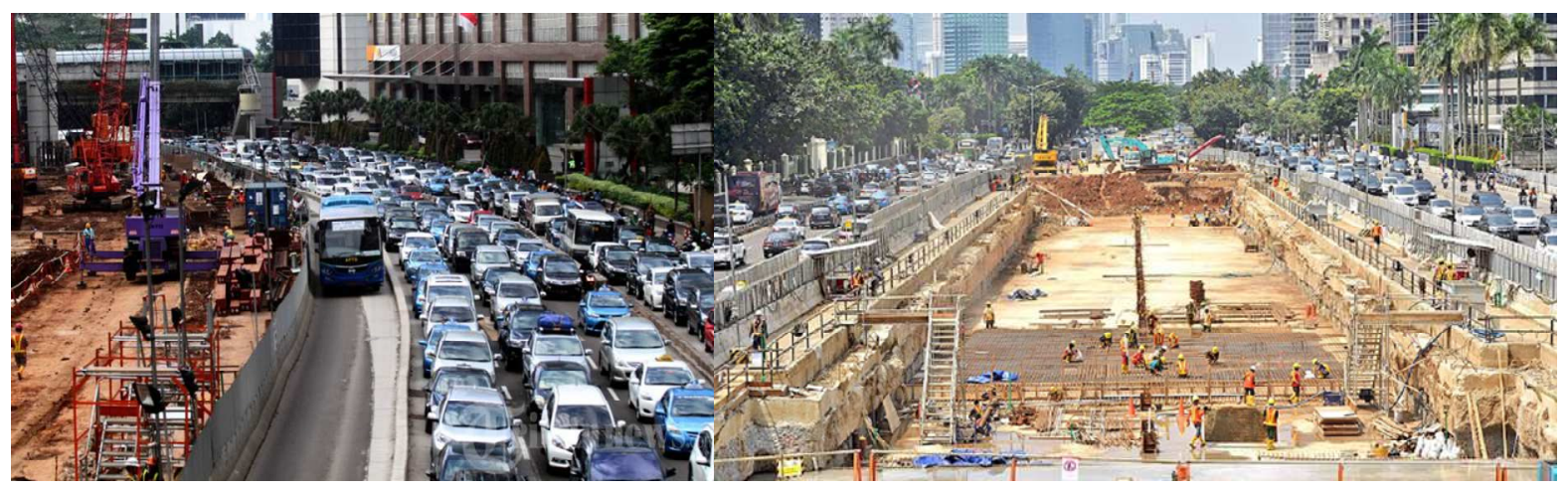

Fig. 8 Managing the traffic flow around the excavation in the North Corridor

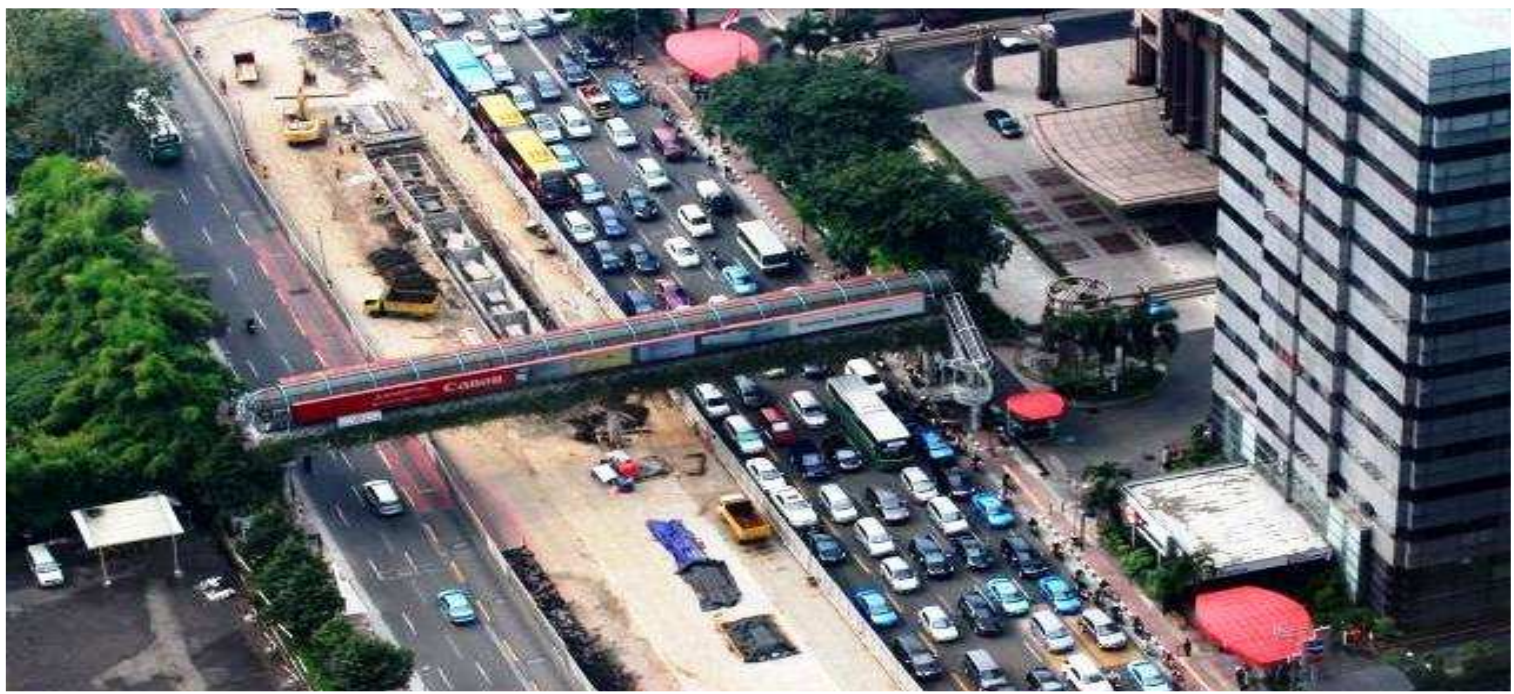

Fig. 9 Traffic Management and Construction Management come into the complexity

Access for vehicles, structural members and concreting in and out of the construction site are in fact, part of the management of traffic. The construction manager shall collaborate with the traffic regulator.

\section{B. Construction Safety and Maneuver of Heavy Construction}

Safety in construction includes:
- Safety during operation of heavy equipment. This can be handled easily since safety requirements can be enforced for all laborers in the construction site. Safety induction and safety regulation are imposed.

- Safety for indirectly people involved in projects like suppliers and visitors.

- Safety of the infrastructure and building in the surrounding area. The movement of the retaining structure during work is crucial. Upon excavation, the 
retaining system move and this may create instability to the surrounding. The design and monitoring system shall take care of this matter.

The most challenging part of the geotechnical challenge of the underground structure is due to the disturbance to the surrounding or neighboring structure during construction of Jakarta MRT. For deep excavation, the soft ground requires protection to keep any excessive movement of the existing structures including roads, public utilities and buildings. As the groundwater elevation is high, the underground opening is subject to buoyancy during construction as well as for permanent structure.

An example of the difficulties is the excavation under the statue at Sisingamangaraja, as it was found that the foundation of the statue was shallow. The target is to protect the statue of any tilting or movement. The retrofit was conducted by the underpinning method. Before the excavation below the statue, many bored piles were constructed and extended steel poles were used to support the statue (Figure 10). The protection has successfully used the Berlin wall to support this excavation.

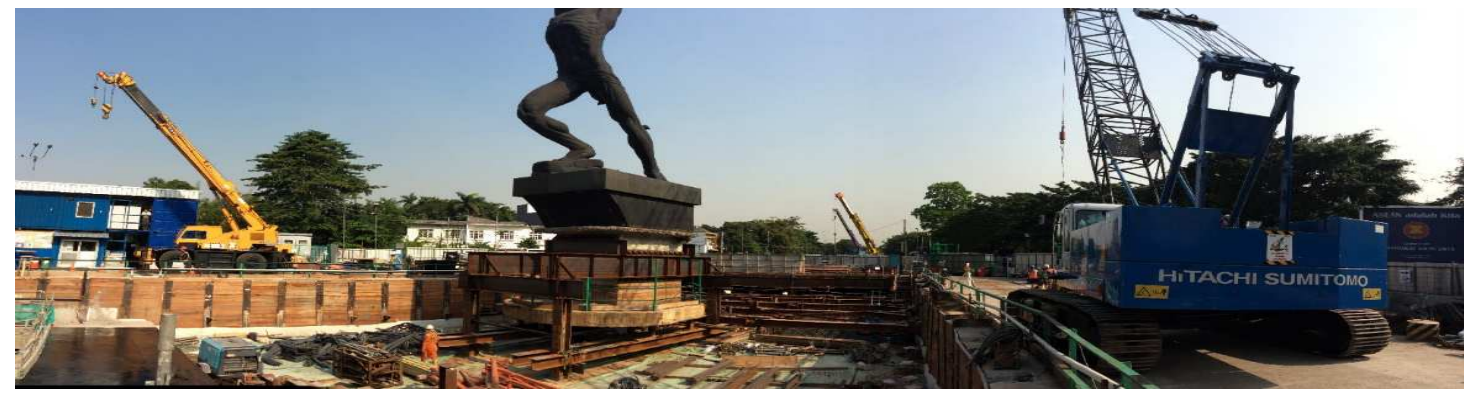

Fig. 10 Challenge in excavation under the statue at Sisingamangaraja

The top-down construction method has been used for deep excavation at the stations (Figure 11). The system is by constructing Dwell with $800 \mathrm{~mm}$ to $1000 \mathrm{~mm}$ thickness embedded into the ground. During excavation, the opening is supported by the floor that is cast before the next deeper excavation and the partial opening is left open for the baby backhoe to go down and also to transport material out of the openings. The reason to use the top-down construction method was due to the wide opening for braced excavation.

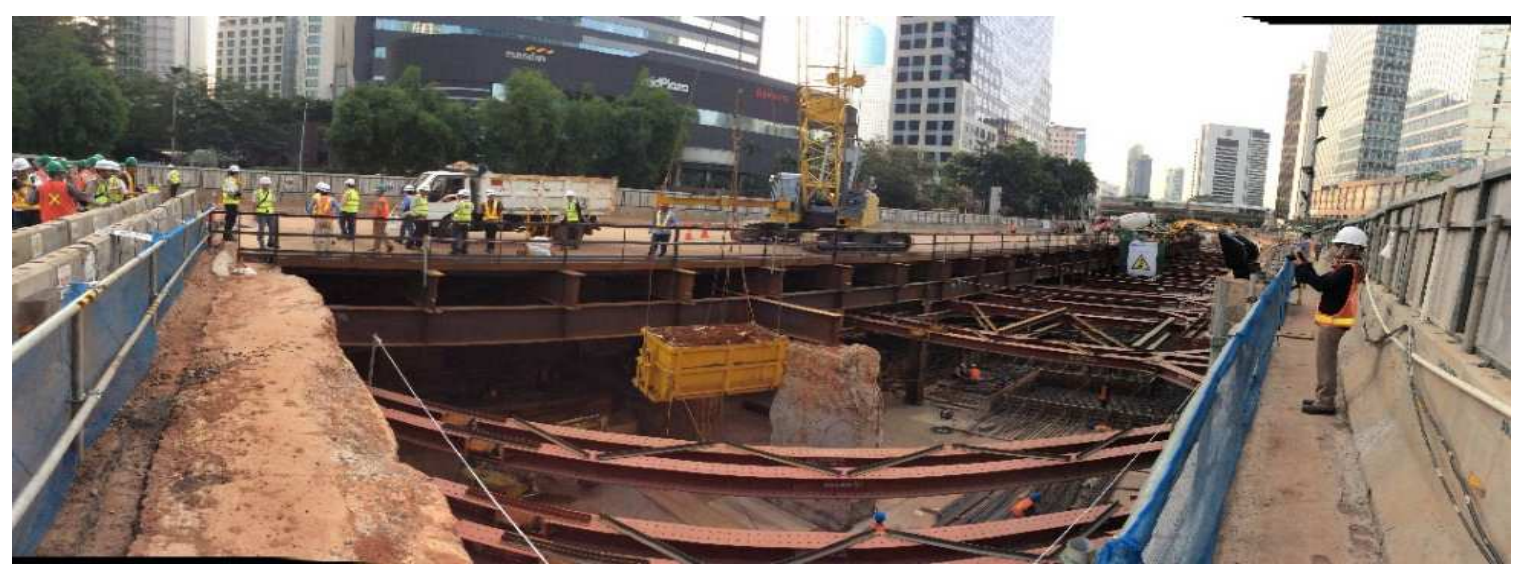

Fig. 11 Top down construction method to reduce traffic disturbance

\section{Management of Ground-Water Flow and Rain Water during Construction}

Although water management seems to be simple, however failure to maintain the construction site dry is one of the keys to the success of the underground construction as shown in Figure 8, Figure 9, Figure 10, and Figure 11. The danger is due to the frequent flood in Jakarta City. The water consists of surface water (mainly due to rains) and groundwater (due to the seepage of groundwater into the excavated areas). The problem of groundwater is because the extraction of groundwater will cause a decreasing water level of the surrounding. In sandy soils, the effect of dewatering could be as far as 150-200 $\mathrm{m}$ away from the construction site. This will increase the effective stresses of the soils and cause settlement of the buildings. To avoid this effect, dewatering by pumping has been prohibited by the Jakarta government and the only way to dewater is by passive dewatering. Water is allowed to seep into the excavation area, collected to the sump pit and then providing pumps standby to dewater when needed.

\section{Effect of Tunneling and Excavation during Construction of MRT}

The effect of dewatering has been discussed in the previous section. Dewatering is part of the construction method in the construction of underground MRT. However, for the deep excavation of the MRT station, some important geotechnical issues shall be addressed:

- The depth of excavation for MRT station varies depending on the location. The shallower part is at 
Istora, and Senayan Station with about $18 \mathrm{~m}$ depth and deepest excavation is at Tunneling might cause lateral movement of the existing foundation, hence causing additional load and internal forces (bending moment and shear).

- The excavation has also caused settlement of the surrounding. In soft soils, the settlement could be as far as four times the depth of excavation, while for firm soils, usually the movement is two times the depth of excavation.

\section{CONCLUSIONS}

The Jakarta MRT is a crucial phase to solve the critical problems of traffic in Jakarta. However, the effectiveness of this system relies on the willingness of the people to use public transport and integrated into all other transportation modes. Furthermore, in transportation engineering perspectives, the management of traffic during the construction of Jakarta MRT is an essential step toward an effective solution to the already dense traffic of Jakarta. The goals are to improve the existing traffic flow and to protect the traffic users due to the movement of heavy equipment and materials in and out of the project site.

Moreover, in Geotechnical perspectives, the challenge in the underground parts can be solved by the use of the topdown construction method for the stations and to use Tunnel Boring Machine for the line between stations. This is made possible if the ground is well identified and the final design is capable of predicting any movement or settlement of the surrounding structures that are kept safe by limiting the displacements. Monitoring is a necessity to prove safety performance as well as for warning systems.

\section{ACKNOWLEDGMENT}

Many thanks to Directorate Research and Community Service, Directorate General of Research Empowerment and Development, and the Ministry of Research, Technology, and Higher Education of the Republic of Indonesia for supporting this research.

\section{REFERENCES}

[1] World Bank. Transforming Transportation (2015) Smart Cities for Shared Prosperity, January 15-16, 2015, World Bank Headquarters, Preston Auditorium, available at http://www.worldbank.org/ en/events/2014/12/18/transforming-transportation-2015-smart-citiesfor-shared-prosperity, accessed February 2015.

[2] BPS Provinsi DKI Jakarta, http://jakarta.bps.go.id accessed July 2018, 2017

[3] Sutandi, A. Caroline. Pentingnya Transportasi Umum Untuk Kepentingan Publik, Jurnal Admnistrasi Publik, Volume 12 Number 1, April 2015, pp 19-34, Social and Political Sciences Faculty, Parahyangan Catholic University, Bandung, Indonesia, 2015.

[4] Button, K.J. And Hensher, D.A. Handbook of Transport Systems and Traffic Control, Volume 3, Elsevier Science Ltd., The Boulevard Langford Lane, Kidlington, Oxford OX5 IGB, UK, 2001.

[5] Sutandi, A. Caroline, "The Significant Importance to Measure Road Safety", Applied Mechanics and Materials, Trans Tech Publications, Switzerland, Scopus Index International Journal, Vol 776 (2015), April 2015, ISSN: 1662-7482, pp 66-73, 2015.

[6] Sutandi, A. Caroline, "Sustainable Urban Transportation in Large Cities in Developing Countries Towards Smart Cities", Conference of the Asia Pacific Weeks - Smart Cities 2015, May 2015, Berlin, Germany 2015

[7] Sutandi, A. Caroline, 'Sustainable Public Transportationtowards Smart City in Developing Countries in Asia", Conferences of the Asia-Pacific Weeks Berlin, "Metropolitan Solutions - Smart Cities", 23 May - 3 June 2016.

[8] A. C. Sutandi and W. Santosa, "Road Safety Improvement in Developing Country Case Study on National Road in Indonesia," in Proceedings of the Eastern Asia Society for Transportation Studies International Conference, 2013, vol. 10.

[9] A. I. Niculescu, B. Wadhwa, and E. Quek, "Smart City Technologies: Design and Evaluation of An Intelligent Driving Assistant for Smart Parking," Int. J. Adv. Sci. Eng. Inf. Technol., vol. 6, no. 6, p. 1096, Dec. 2016.

[10] Van der Meulen, G.,G., "Urban Geology Challenging Human Settlement Development in Asia and the Pacific," proceeding International Conference on Urban Engineering in Asian Cities in the 21st century, Asian Institute of Technology, Bangkok, Thailand, 1996.

[11] Sanit, Peamsok, el.al. Analysis of Location Choice Behavior and Urban Railway Commuting of Bangkok's Households, Urban and Regional Planning Review, Volume 1, 2014, 2014.

[12] Orosa, Rosalinda L., DOTC stands firm on Decision to Locate LRTMRT Common Station at Trinoma, The Philippines Star, http://wwww.philstar.com, 2014.

[13] Robert Adhi, KSP., "Menunggu Janji MRT dan LRT di Jabodetabek Terwujud, ", Kompas, 14 April, 2015.

[14] P. P. Rahardjo, "Different Methods of Excavation for Basement in Jakarta: Design, Reality, and Associated Problems," in Proceedings of the 2nd International Symposium on Asia Urban GeoEngineering, 2018, pp. 184-203.

[15] Rahardjo et al, "Liquefaction Study due to earthquakes in the Jakarta Area," report submitted to PT Agung Sedayu Development, 2015.

[16] H. Rezaei, A. A. Jafarzadeh, A. Alijanpour, F. Shahbazi, and K. V. Kamran, "Effect of Slope Position on Soil Properties and Types Along an Elevation Gradient of Arasbaran Forest, Iran,” Int. J. Adv. Sci. Eng. Inf. Technol., vol. 5, no. 6, p. 449, 2015. 